\title{
AN EARLY-MEDIEVAL HELMET OF THE STROMOVKA-GNEZDOVO- BOJNÁ TYPE FROM THE COLLECTIONS OF THE KOZEL CHATEAU
}

\author{
PAVEL MACKU゚ - VERONIKA PILNÁ
}

In memory of PhDr. Vladimír Goš, CSc. $(* 8.9 .1942-\uparrow 15.1 .2020)$

\begin{abstract}
The collections in the Kozel chateau involve a section of the former archaeological collection from the castle museum. One of the items is a metal helmet of the Stromovka-Gnezdovo-Bojna type, probably from the 9th-10th century. No further information or documentation regarding the find has been preserved, which also applies to the rest of the objects from Kozel. This article seeks to compare the helmet with analogies and to disclose the circumstances which might have led to its finding, as well as its following history.
\end{abstract}

Key words: early Middle Ages - helmet - Kozel chateau.

Abstrakt: V mobiliárním fondu zámku Kozel je uloženo malé torzo někdejši archeologické sbírky zámeckého muzea. Jedním z předmètů je kovová přilba typu Stromovka-Gnězdovo-Bojná, pravděpodobně z 9.-10. století. Stejně jako k ostatním nálezům ze zámku Kozel se k ní nedochovaly žádné pưvodni informace nebo dokumentace. Cílem textu je porovnat tento dochovaný kus s analogiemi a vypátrat pravděpodobné okolnosti, které mohly vést $k$ jeho nálezu, a jeho následné osudy.

Klíčová slova: raný středověk - přilba - zámek Kozel.

Although it is often said that in the period of Romanticism archaeology was the domain of the bourgeois intelligentsia (Sklenár 2017, 12), there were also major contributors from the ranks of the aristocracy who built up small collections of antiques in their residences. These collections were usually strictly private and largely served for the personal presentation of the owners before visitors, or were made accessible, under certain conditions, to a wider audience. Chateau collections comprised various types of items, yet the most attractive exhibits included weapons, armours and their parts. These collections of "antiques" were supplemented by gifts and purchases, and one of the sources to expand them was also early archaeology.

\section{The Št’áhlavy region and early archaeological research}

The town of Štáhlavy is situated 14 kilometres south-east of Pilsen (in Czech Plzeň), on the River Úslava. It is an area which in the past counted among the most densely populated ones, as confirmed by numerous archaeological sites from the period of the late Stone Age onwards (Pilná-Kasl-Jíchová 2020). The historical Štáhlavy demesne was a dominion administering 50 villages with a headquarters in Štáhlavy (Batěk 1967). Mentions of the first planned excavations come from František Xaver Franc (1838-1910) who in his work Štáhlauer Ausgrabungen 1890 refers to research initiated by Count Christian Vincent of Waldstein-Vartenberk: "[...] in the upper castle everything had long been dug up, and also later, as I was told, under Christian Count of Waldstein-Vartenberk who in 1816 inherited the Štáhlavy demesne from Czernin of Chudenice. The forest chateau of Kozel holds an impressive collection of the tips of iron arrows, nice floor tiles, parts of armour and other finds from this period [...]" (Franc 1988, 188). However, no further mentions or records of Waldstein's excavations have been found, and presumably even a simple form of documentation was not actually needed in the Romanticist phase of the discipline.

A key part, both in the Štáhlavy area and the budding Czech archaeology, was played by research conducted by the mentioned František Xaver Franc. During his service to the Waldstein dynasty as the gardener at the Kozel chateau in 1871-1892, Franc started to investigate, in particular, the burial mounds in its vicinity. He kept records regarding the individual excavations that were exceptionally detailed for his time and contained both verbal descriptions and picture 
documentation of finds, and often also the sites. Franc predominantly centred on prehistoric sites, and medieval finds including the early phases were not so attractive for him in comparison. Although the items that he unearthed include militaria, no object that could be identified as a helmet is described in Franc's preserved documentation.

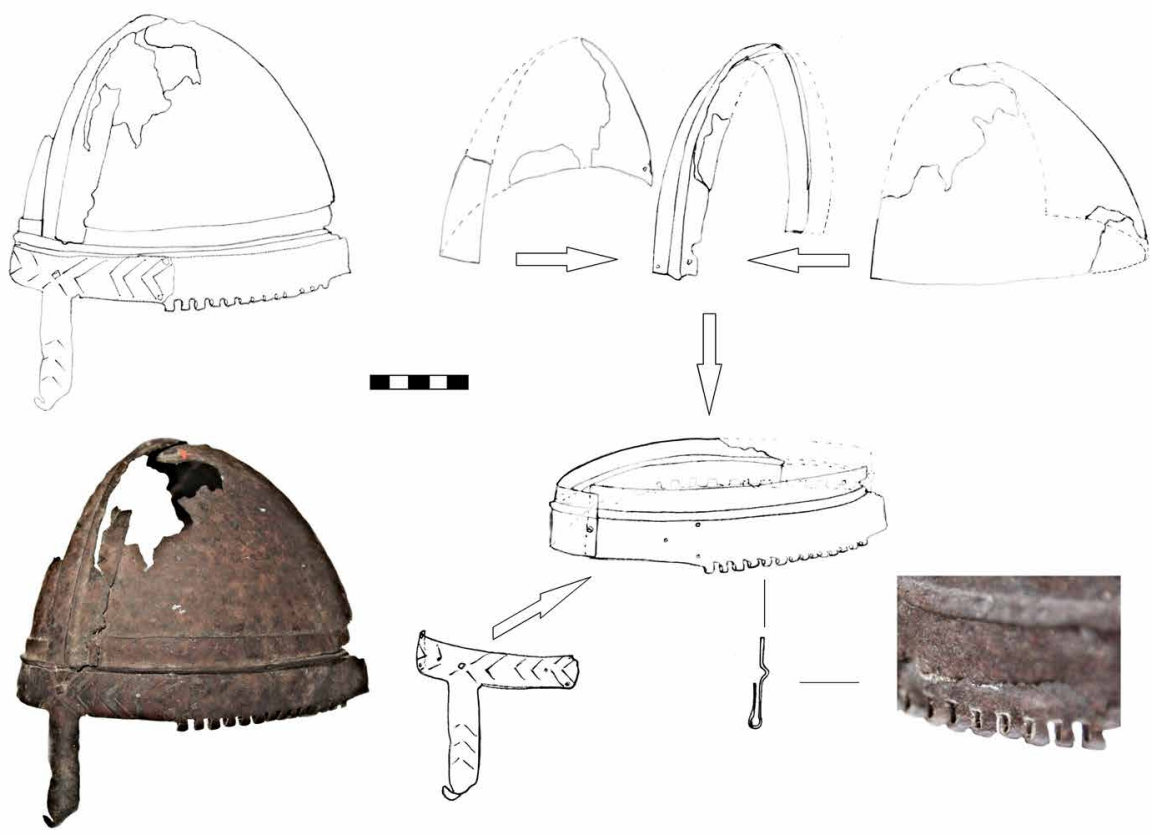

Fig. 1. Helmet construction. Bottom right, detail of the inner side of the border including profiling. Photo and drawing P. Macků.

Obr. 1. Konstrukční řešení přilby. Vpravo dole detail vnitřní strany lemu věetně profilace. Foto a kresba P. Macků.

\section{The Waldsteins, early archaeology and the Kozel collection}

The Waldsteins were renowned antique collectors in the course of the 19th century. Their collections were scattered at chateaus owned by the different lineages of the family. The Czech scholar Josef Dobrovský, for example, took an interest in the figurine of an "ancient Slavic god" from Hradec Králové which was in the collection at the Duchcov chateau (Sklenár 2000, 251). Waldstein collections including those of "antiques" were housed at the Duchcov chateau, in the chateau in Mnichovo Hradiště, in Prague, and also in the Kozel chateau, near Štáhlavy. The first Waldstein owner of Kozel was Christian Vincent of Waldstein-Wartenberg (Vartenberk; 1794-1858) who inherited the Štáhlavy and Nebílovy demesnes including the Kozel chateau, then also referred to as a "Waldschloss," in June 1816 from his great-uncle Jan Vojtěch Czernin of Chudenice (1746-1816). Before Christian inherited the family seat in Mnichovo Hradiště in 1832 and turned his attention there, he had spent a great deal of time at Kozel. As he noted in his memoir, after his wedding in 1817 he would spend every summer in the Štáhlavy region and winters usually in Vienna; he would only stay in Prague sporadically. Kozel was also the birthplace of some of his children. His memoirs as well as various activities documented, for example, in relation to the 
Czech Museum (later the Museum of the Kingdom of Bohemia, today's National Museum) show that he was interested in history and "antiques" (Goll 1898, 246). For example, when in 1833 he hosted in Mnichovo Hradiště a meeting between the Austrian emperor, the Russian tsar and the Prussian crown prince, he made a note of how the ruin of the Valečov castle served as a destination of trips of this noble society during the meeting. Presumably, a similar sentiment was behind his decision to explore the nearby ruin of the Lopata castle, as mentioned by František Xaver Franc (Franc 1988, 188). The first excavations took place between 1816 and ca 1835, since Sommer in his Topografia from 1838 writes: "[...] approximately half a mile into the woods lies a castle ruin usually called the old castle, which was once owned by a knight named Lopata. Iron arrows, spurs, parts of chainmail, etc. were found there" (Sommer 1838, 82). Christian Vincent donated to the Czech Museum three historical objects - two stone coats of arms of Václav Budovec of Budov with Czech inscriptions from the ruin of the Zásadka castle and a sword attributed to Christopher Columbus (Zap 1854, 45). In the last years of his life he was on the Archaeological Museum
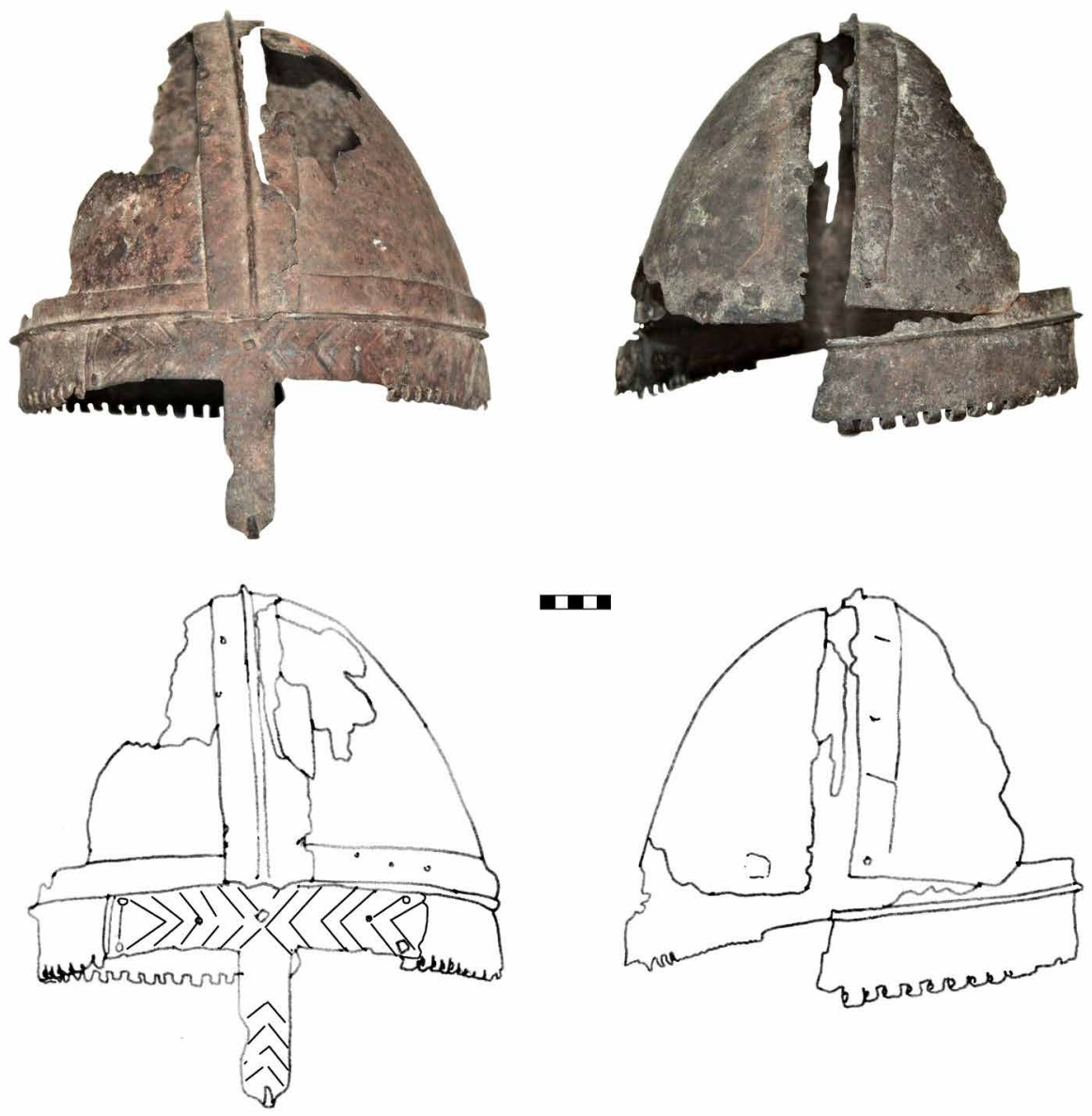

Fig. 2. Helmet from the Kozel chateau collections, front and rear views. Photo and drawing P. Macků.

Obr. 2. Přilba ze sbírek zámku Kozel, přední a zadní pohled. Foto a kresba P. Macků. 
Committee and in 1852 was appointed president of the Czech Museum. A letter from Erazim Vocel from 1852 has been preserved in which he appeals to Christian Vincent to accept the presidential office. However, Christian Vincent's interest in history and indirectly in archaeology also had pragmatic roots; in 1841 he tried to gain the right to use the title of Duke after his ancestor Albrecht of Waldstein. From today's perspective, Christian was an ardent promoter of history and archaeology. If the observed helmet made its way to the Kozel collection in his lifetime, either as a random find from the castle vicinity, as a gift or through deliberate romantic explorations, it is highly probable that no note of the manner of its discovery was made. It is not certain whether Franc knew it from the original old collection and filed it under "parts of armour" when assessing the first attempts at excavations at the Lopata castle.

Another important initiator of research in the Štáhlavy region was Ernst Karl of WaldsteinVartenberk (1849-1913) who supported F. X. Franc in his excavations in the vicinity of the Kozel chateau. After a short military career he pursued his penchant for history; for example, he collected archivalia and old prints and even wrote articles on the subject of antiques. The journal of the north-Bohemian hikers' club published in 1893 his article devoted to the finds from Dauba (in Czech Dubí), "Eine Gräberstätte bei Dauba" (Waldstein 1893, 1-22). He published two articles in the specialist journal Mittheilungen der kaiserl. königl. Central-Commission zur Erforschung und Erhaltung der Baudenkmale on Runkelstein Castle: "Die Wigalois-Bilder im Sommerhause der Burg Rungelstein" in 1887 and "Nach-lese aus Runkelstein" in 1894 (Waldstein 1887, 159-165; 1894, 1-7). Moreover, he donated several finds from the Kozel collection to the newly established Naturhistorisches Museum in Vienna. After Franc left the service at Kozel, Ernst Karl supported further excavations in the surroundings and in Starý Plzenec where research was led by eminent figures of west-Bohemian museology, Josef Strnad from Pilsen and Bohuslav Horák from Rokycany (Horák 1908-1909). The archaeologist Josef Ladislav Píč regularly took part in the research as a consultant (Kondelík 2012, 61). Ernst Karl also financially supported the restoration of medieval frescos in the local parish church (Plzeňské listy 1906). After his death the Štáhlavy demesne was inherited by his brother Adolf, who in 1920 donated the Kozel collection built by Franc and supported by Ernst Karl to the Pilsen museum (Macháček-Strnad 1926, 27). When the collection was made over to the museum, Fridolín Macháček wrote in a contribution to the Almanac of the Municipal Historical Museum in Pilsen in 1926 an extensive description of its content. The prehistoric section consisted of 582 reconstructed vessels, 7,506 sherds and fragments of vessels, 11 gold objects, 589 bronze ones, 603 stone ones, 74 iron objects, 205 clay ones, 113 bone items, 2 amber ones, 2 glass beads and others; 10,367 items in total. The medieval section contained 21 complete vessels, 550 sherds of vessels, 2,341 sherds of floor tiles and tiles, 5 complete tiles, 1,474 iron objects and several made of different materials, i.e. 4,420 items in total (Macháček 1926, 33-34). Franc's lists had been lost by then, so in the interwar period this was the most comprehensive description of the collection known. In 1959, however, the authors of the article Burial Mounds at Hájek, near Štáhlavy, Pilsen District noted: "The collection, though incomplete - Waldstein had kept some important objects - then contained 10,367 items" (Jílková-Rybová-Šaldová 1959, 54-55). This illustrates the fact that after the nationalization started in 1948 items recorded in "black books" by the local Cultural Committee also included archaeological finds that were then still located among the equipment of the Kozel chateau (Kozel Chateau Inventory, "black book", undated, 11).

Although due to the situation in 2020 we were unable to complete in-depth research into archive material regarding Ernst Karl of Waldstein, and thus cannot confirm whether a record of the find or donation of the helmet has been preserved or not, it is highly probable that the helmet was in the corpus of "important objects" which were not part of Adolf Waldstein's gift to the Pilsen museum in 1920. However, if it had been found by F. X. Franc, it would have appeared in his documentation as a significant object. There is another possibility given the background: the helmet does not come from the Pilsen region or from the Czech Republic. One must hope that archive research in the future will bring information about its origin. 

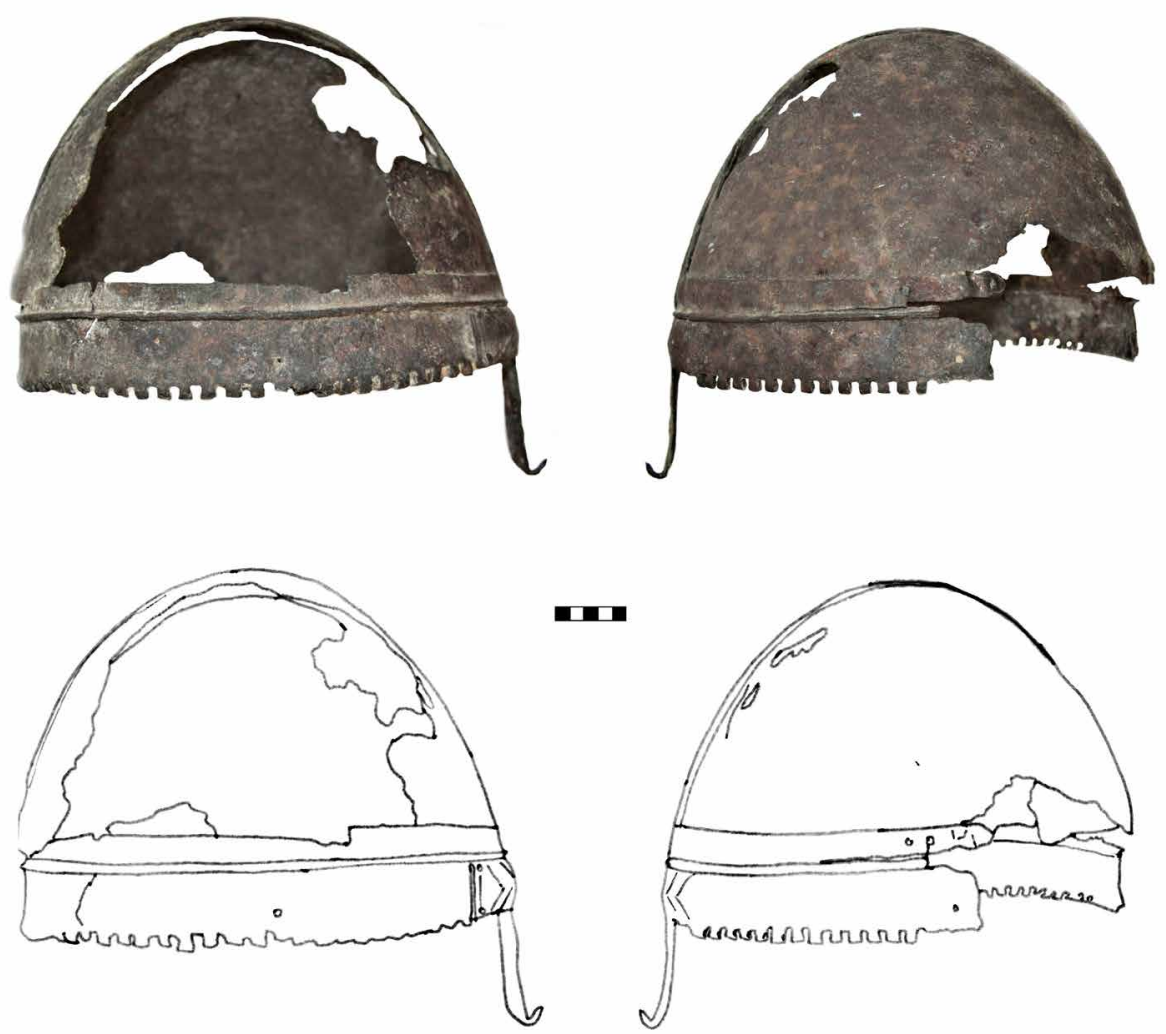

Fig. 3. Helmet from the Kozel chateau collections, side views. Photo and drawing P. Macků.

Obr. 3. Přilba ze sbírek zámku Kozel, boční pohledy. Foto a kresba P. Macků.

\section{Description and construction of the helmet}

The helmet ${ }^{11}$ from the Kozel chateau is preserved in two fragments under inventory number KZ 3480 (original no. 249/bč/134). The bigger part weighs 669 grams, the fragment of the right section of the skull weighs 34 grams, i.e. 703 grams in total (the left and the right side are described from the perspective of the person wearing it and describing it). A fragment of the skull, according to the file card of the CastiS system, broke off during the study of the helmet on 4 May 1984. The helmet was riveted from five parts (Fig. 1). It consists of two separate quarter-spherical segments joined at the centre with a strip comb with a rib and which are also riveted by the bottom border with a strip with holes for the attachment of chainmail. A T-shaped nosepiece with relief decoration is fixed in the place of forehead. The external perimeter of the helmet was ca $65 \mathrm{~cm}$; this is an estimate given the fragmentary nature of the find, yet highly probable. The length from the neck to the forehead (without the nosepiece) is $41.5 \mathrm{~cm}$. The height of the helmet including the nosepiece is $21.5 \mathrm{~cm}$, the width is also $21.5 \mathrm{~cm}$.

1 Our great thanks for a consultation and access to an extensive specialist library go to Tomáš Vlasatý. T. Vlasatý is currently preparing a catalogue of early medieval helmets from the 9 th -12 th centuries which we could access in manuscript form. 
The manufacture of the helmet involved several steps. The basic part consists of a border of a single sheet which makes the bottom section of the helmet ${ }^{22}$, and its beginning and end join in the place of forehead, under the nosepiece. The right section is hammered at the end and the left section was folded over it (Fig. 5: bottom, Fig. 8: above). In this place the sections were held together by a rivet whose square head $4 \times 4 \mathrm{~mm}$ is still preserved on the helmet and attached, together with four more circular ones, the nosepiece to the base (there are two more holes after two lost rivets and three more holes around the square head one, as it can be seen only on X-ray: Fig. 7). The border of the helmet was thus attached to the nosepiece probably with seven rivets, five of which are preserved (Fig. 2, Figs. 5-7). The border in the straightened form was shaped like a strip widening ca $7 \mathrm{~cm}$ from both ends at the bottom, and in it were bored and filed rectangular apertures. In the following step the border was folded across the centre of these apertures, which created individual fixtures for chainmail. Judging by the drop-shaped widening of these fixtures, the piece was probably shaped by bending over a log (Fig. 1: bottom right). There are square hole on both side of border most probably for attaching fastening strap.

The helmet appears delicate, which is given by the thinness of metal resulting in its lightness. The left fragment of the skull is $0.25-1.5 \mathrm{~mm}$ thick by the bottom edge, in the upper sections it is $0.2-1 \mathrm{~mm}$ thick. Another fragment of this part, still in the helmet construction, in the place of the right temple, is $0.19 \mathrm{~mm}$ thick in the fracture. It is similar with the right section of the skull where the thickness is between $0.2-1.5 \mathrm{~mm}$ by the bottom edge and in the upper section, in the place of fracture on the front, $1.1 \mathrm{~mm}$. It should be pointed out that values under $1 \mathrm{~mm}$ were measured at fractures, and corrosion and other factors were probably involved. The thinning of the metal from
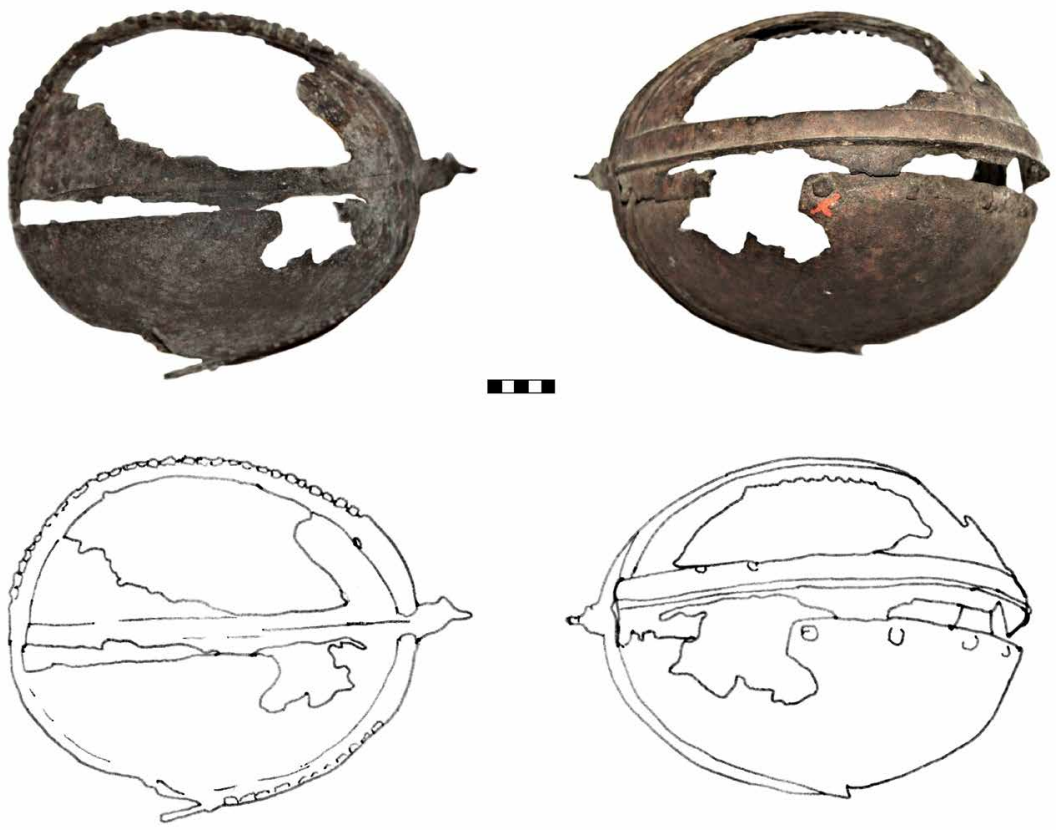

Fig. 4. Helmet from the Kozel chateau collections, bottom and top views. Photo and drawing P. Macků. Obr. 4. Přilba ze sbírek zámku Kozel, dolní a horní pohled. Foto a kresba P. Macků.

2 Material analyses have not been conducted due to the coronavirus pandemic. They will be the subject of further research before the conservation of the helmet and will be published separately. We are grateful to MVDr. Markéta Tučková from Veterinary clinic Kleisslova, Pilsen, for X-ray analysis. 
the centre towards the edges might have been produced by the hollowing technique (Brožek 2021, 70-71, Figs. 4.23-4.24). Both parts were thus made of a metal sheet hammered to the thickness of 1-1.9 $\mathrm{mm}$. The material of the comb was metal $1.5 \mathrm{~mm}$ thick, as was the metal of the border. The horizontal bar of the T-shaped nosepiece was $13 \mathrm{~cm}$ long and $2.1 \mathrm{~cm}$ tall and is made of thinner metal. Owing to the attachment to the base, only its edge section can be measured, which is visibly thinner towards the edge $(0.1 \mathrm{~cm})$ and is thicker towards the centre. The vertical section protecting the nose is $7.8 \mathrm{~cm}$ long and $1.8 \mathrm{~cm}$ wide, the material is $0.2 \mathrm{~cm}$ thick on the left and $0.3 \mathrm{~cm}$ on the right and $0.25 \mathrm{~cm}$ thick by the bottom edge.

The rivets used in the construction of the helmet have irregular circular or rectangular heads with the dimensions of $5 \times 3.5 \mathrm{~mm}$ at the most. The rivets or the apertures for them fixing the comb on both its sides to both parts of the skull are approximately $4 \mathrm{~cm}$ from each other and there were originally nine in total on both sides of the comb. There are seven preserved on the right, eight have been preserved on the left (one rivet has fallen out, Fig. 6, 8-10). There are another fourteen rivets or apertures for them preserved on the helmet, attaching the parts of the skull to the liner (on both side have preserved five rivets); one of them and one hole is preserved in the individual fragment of the right half of the skull (Fig. 8: bellow). The exact position of the fragment of the skull towards the liner is confirmed by a horizontal negative imprint created by corrosion by its bottom. The only rivet with a square head found in the centre of the nosepiece is described above $(4 \times 4 \mathrm{~mm})$. Another two rivets were probably identical, found centrically from it in the horizontal section of the nosepiece. Both are now lost. Four more, one in each corner, attach the nosepiece to the skull in the horizontal section. Between these rivets there is engraved decoration in the form of pointed lines along the grooves of the same shape which create three thick rafter shapes on both sides (motif of an ear of corn, evergreen branch or fishbone). The tips of the rafters point towards the central rivet. The rafter shapes on the left are done meticulously. Identical ones made up of four pointed lines but less visible are on the vertical bar of the nosepiece and their tips point up from the rounded end, towards the central rivet (Figs. 2, 5-7).

\section{Historical context and analogies}

The need to protect the face in battles gave rise to various forms of visors. With the intention of killing the opponent, the head makes an ideal target, which is why descriptions of head injuries are frequent in old literature. Several mentions in a memoir of a Champagne knight called Jean de Joinville come from the mid-13th century; in 1248-1254 he took part in the Seventh Crusade to Egypt. Thanks to his colourful depiction we know that Érard of Sivra "[...] was cut in his face by a sword so deeply that his nose hung over his lips [...]", or that Hugo of Écot was injured three times in his face by a spear. The knight also describes the injuries of Peter of Brittany who "[...] was wounded by a sword in his face, and blood was streaming down his mouth [...]", and Brother William, Master of the Knights Templar who "[...] lost an eye in this battle, had lost the first one on the previous Shrove Tuesday, and this lord died as a consequence [...]" (of Joinville 2014, 66, 69, 76).

Nosepieces, both detachable and fixed to the helmet or its parts, were some of the most simple and most practical variants of how to protect the vulnerable face. This solution was already known in ancient Greece, was employed in the early and high Middle Ages as well as in the early modern age. The issue of early medieval helmets has been regularly addressed (Bravermanová et al. 2019, 261-271; Hejdová 1964, 41-91); we will just sum up here that ribbed, belt and conical helmets were used in Europe in the early Middle Ages. The last group included helmets assembled from parts and those made in one piece, sometimes called Norman helmets after many depictions in the Bayeux Tapestry (Blair 1959, 21, 25-27, Fig. 2; comp. Laking 1920, 32-33, 42-44, 57, Fig. 71). Their nosepiece was forged directly with the helmet or was attached on the front. The nosepiece protected the wearer's head from sword wounds, directing the enemy's weapon away from the face. At the same time, these helmets did not limit the owner's vision and air circulation, which is why they were popular in modifications until the 13th century when they 

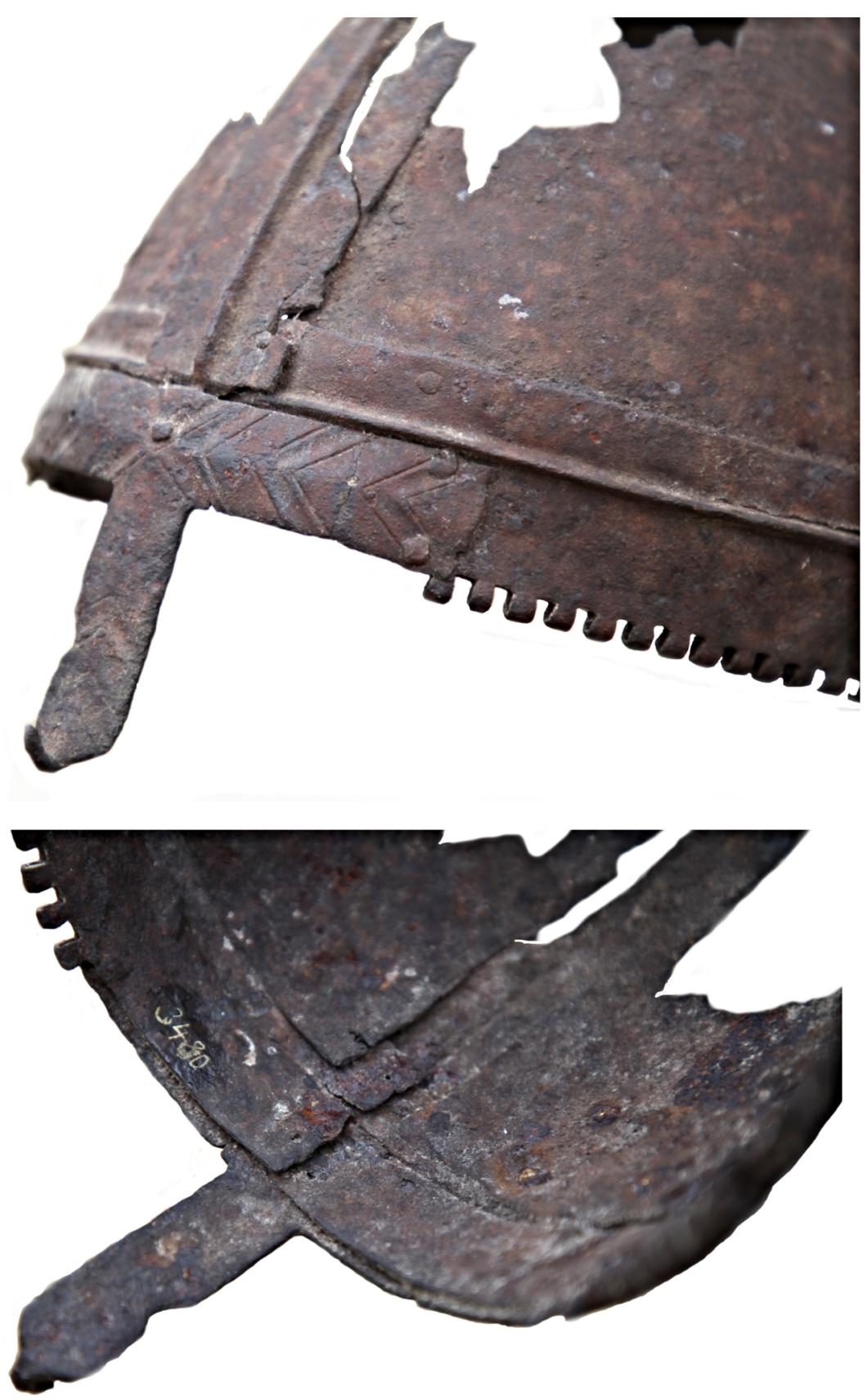

Fig. 5. Detail of the construction of the helmet and nosepiece. Photo P. Macků.

Obr. 5. Detail konstrukce přilby a nánosníku. Foto P. Macků. 
disappeared around its half (Hejdová 1964, 41-91). Their replacements in the form of chain and later metal nosepieces on chain fixtures attached to the chin were followed in the 14th century by metal nosepieces, later nosepieces that could be lifted (for helmets of the high Middle Ages, especially in relation to nosepieces, see Knápek-Macků 2016, 168-175; Macků-Pilná 2020, 394-395; Strong 2018). Nosepieces occurred in this form until the times of King Wenceslas IV when they featured on some kettle helms; the best-known representation from the Czech milieu is in the Resurrection of Christ painting by Master of the Třebon Altar, now in the National Gallery in Prague (Charles IV, 2006, 502-507, Fig. VI.7). This simple and practical solution never disappeared completely and continued to the early modern age, for example, with "Pappenhaim helmets" from the 17 th century.

Conical helmets can be divided based on their construction into those with a skull forged of a single piece or assembled from several parts. The best-known early medieval helmet with a skull

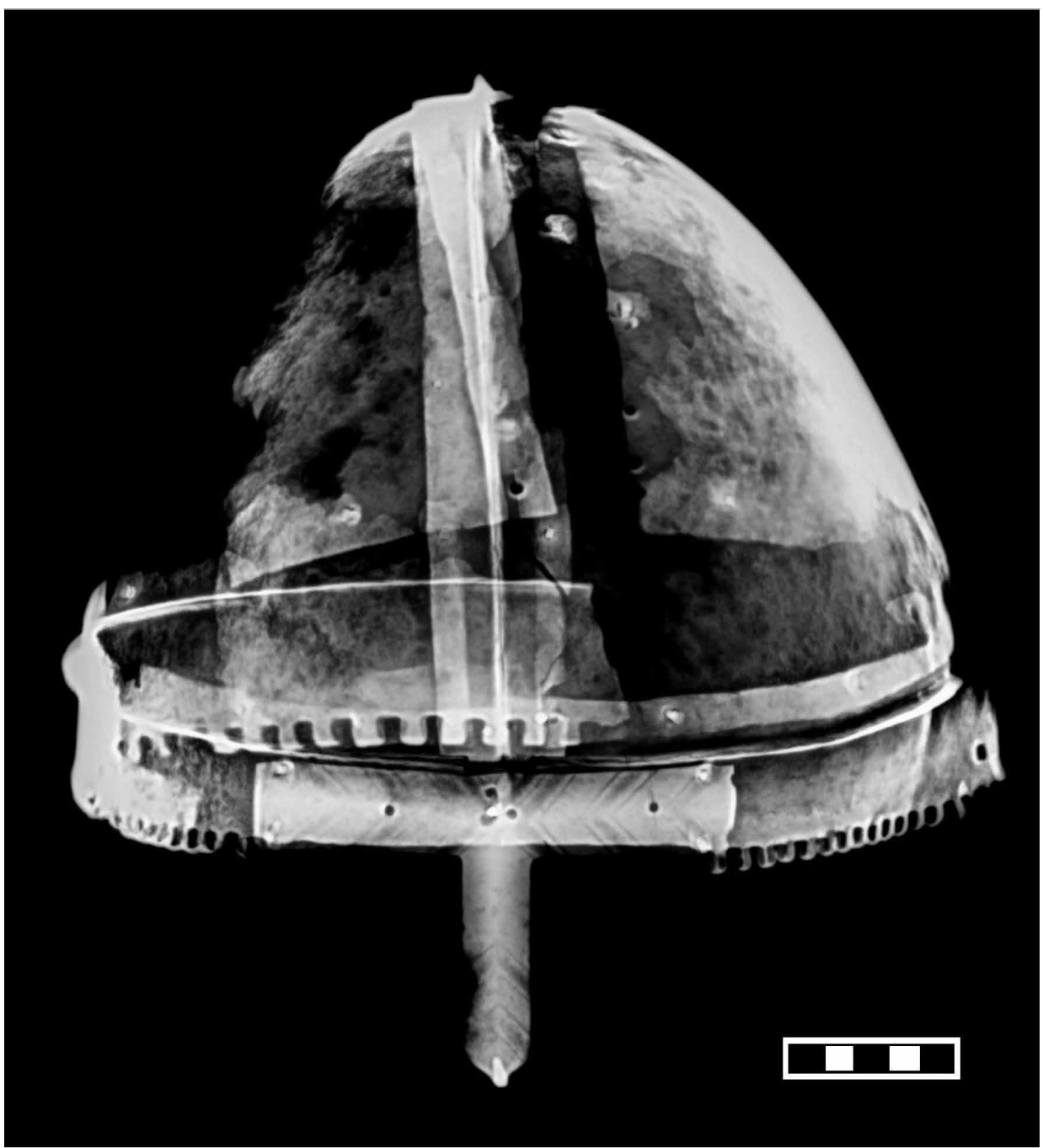

Fig. 6. Helmet from the Kozel chateau collections, front view in X-ray. Photo M. Tučková, modified by P. Macků. Obr. 6. Přilba ze sbírek zámku Kozel, přední pohled v rentgenovém snímku. Foto M. Tučková, úprava P. Macků. 
of a single piece in this country is, beyond doubt, the specimen attributed to St. Wenceslas. The helmet is part of the crown jewels housed in St. Vitus' Cathedral of the Metropolitan Chapter, Prague (inv. no. K 168). It consists of a one-piece skull, an individual nosepiece and further smaller parts including modifications joined by riveting (for the production technology of singlepiece helmets see Brožek 2021, 70-74, Fig. 4.32; comp. Klepač 2008, non-pag.). The total weight of the preserved parts is 1053.3 grams. The helmet has been examined and conclusions revised since the mid-19th century, and it has been linked to different owners, with origin sought in Western Europe through northern Europe to eastern Europe, between the 9th-11th century. The present opinion is that the skull was probably made in the 10th century, its original nosepiece was later removed and attached to the system for the hanging of chainmail. Around or after the year 1000 a new, present nosepiece and border were added with the use of imports from Northern Europe. The final modifications involved a patch and the re-attachment of the border, which can be associated with the status of the helmet as a relic. The thickness of the material of the skull ranges from 0.6 to $2.2 \mathrm{~mm}$, the nosepiece is $5 \mathrm{~mm}$ thick by the bottom, the border is $4 \mathrm{~mm}$ thick. The heads of the rivets are $12 \mathrm{~mm}$ in diameter (Bravermanová et al. 2019, 237, 245; Klepač 2008, non-pag.).

A more comprehensive approach to the assessment of this helmet was brought by the works of D. Hejdová published from the 1960s onwards, and most recently the team of researchers led by M. Bravermanová which also explored other parts of St. Wenceslas militaria (Bravermanová 2011, 217; Bravermanová et al. 2019, 236-247, 279-281; Hejdová 1964, 1-106; the cited works include older literature). According to the most recent interpretations, the helmet might have indeed belonged to St. Wenceslas when it represented a one-piece product forged with a nosepiece, without chainmail but with inner lining. The first modifications in the form of a chainmail fixture were added after the loss of its military value, i.e. when the helmet was already viewed as a relic, i.e. in the late 10 tth century or in the early 11th century, perhaps even later. At the same time, the original nosepiece was filed off and replaced with the present one and other elements connected with the rim (Bravermanová et al. 2019, 297-301).

The pair of helmets uncovered during ploughing in 1890 or 1891 at a hillfort near Mšeno (Mělník district) is probably of the same age; these helmets are referred to in literature as Hradsko 1 and 2. Both are single-piece helmets and due to post deposition processes are distinctly flattened. Helmet no. 1 is located in the Terezín depository of the National Museum under inv. no. H1-231930. This helmet has no nosepiece, yet its existence cannot be ruled out. Helmet no. 2 is also found in the National Museum, under inv. no. H2-101752. It is similar to the first one but has a $3.5 \mathrm{~cm}$ long nosepiece preserved which might have been longer. Both helmets have a row of holes along the border for the attachment of the inner lining. Their origin is sought in this country or in the broader European region, the dating oscillates between the 8th/9th century and the 11th century. The most recent opinion of their dating is around the mid-10th century (in more detail with quotes from older literature in Bernart 2010, 18-22; Vlasatý in press).

Another three helmets were believed to come from Moravia (Laking 1920, 45, 46, Figs. 56-58); however, this was actually confusing publishing of the same find and needs to be revised. The first helmet was discovered in Olomouc - provostry and since 1864 has been in the Kunsthistoriche Museum in Vienna. It has a shape of a tall cone with a broad nosepiece above which, towards the top, it is formed into a dull edge. The nosepiece has a small hook on the bottom edge. On the perimeter there are holes for the attachment of the inner lining. The helmet is dated to the 11th-12th century (Hejdová 1964, 84-86; Laking 1920, 45; Měŕínský 2009, 220; Píč 1890, 7; Thomas-Gamber 1976, 36-37, Fig. 4; Beaufort-Pfaffenbichler 2005, 50-51). According to Laking, the second helmet was found near Olomouc and was only published in his work, and was allegedly also housed in the Kunsthistoriche Museum. Its shape was very similar to the first one, but the nosepiece with a hook was longer (Laking 1920, 45-46, Fig. 57). However, this is probably the same helmet, as indicated by another confusing specimen described further. 

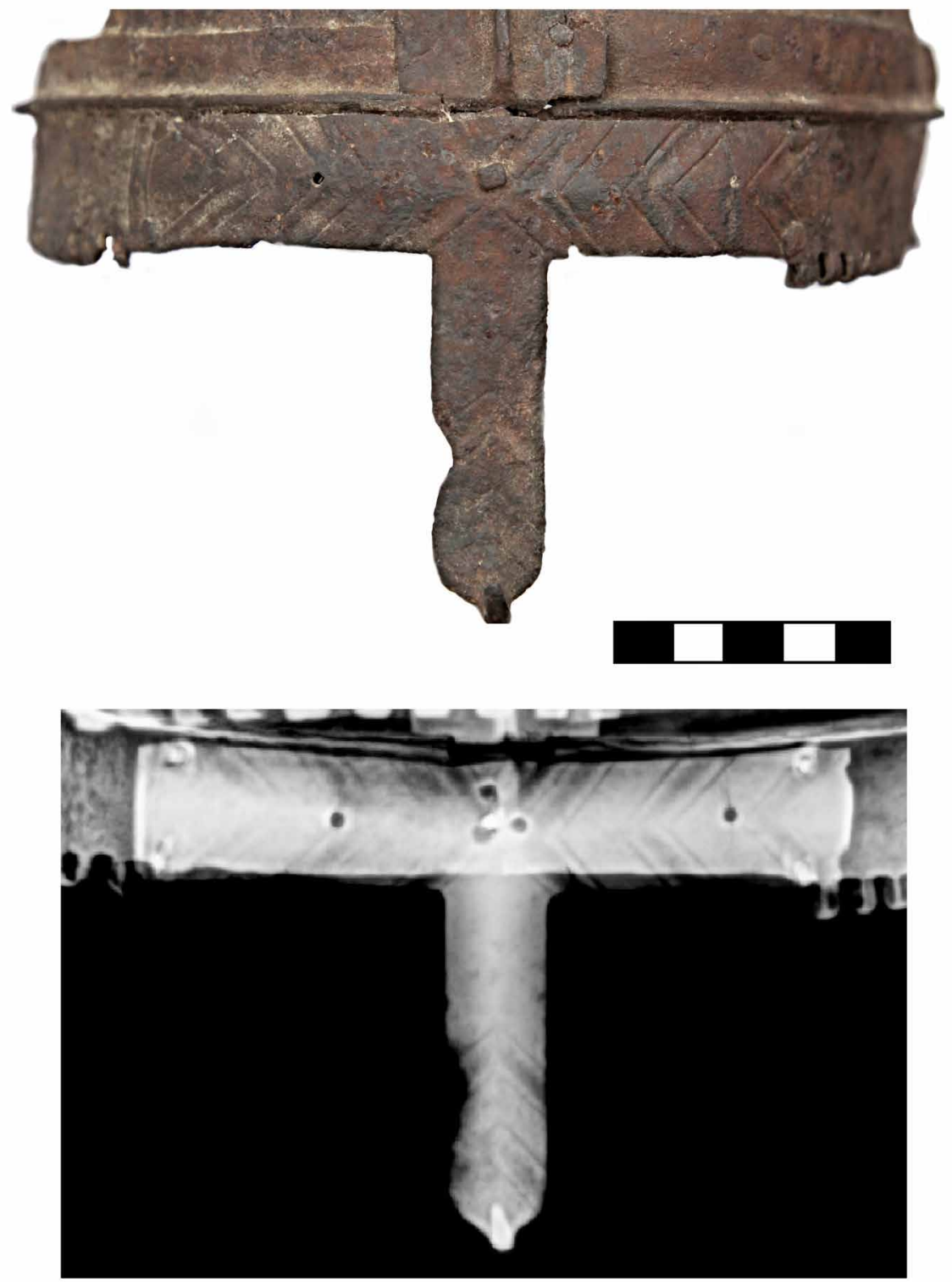

Fig. 7. Detail of the nosepiece construction. Photo M. Tučková, P. Macků, modified by P. Macků.

Obr. 7. Detail konstrukce nánosníku. Foto M. Tučková, P. Macků, úprava P. Macků.

The south-Moravian specimen published in the same book was part of grave goods from an unspecified location dated to the 11th century, and in the time of its publishing was in the collections of Count Hans Wilczek in his Kreuzenstein residence near Vienna. The helmet has been lost since the First World War (Hejdová 1964, 84; Laking 1920, 45-46, Fig. 58). Owing to its similarity to the helmet from Olomouc - provostry, it has been suggested that it was the same one. Both have a very similar skull shape, and the photo of the helmet from Olomouc - provostry published by Laking has in contrast to the one from Count Wilczek's collections, only a bent 

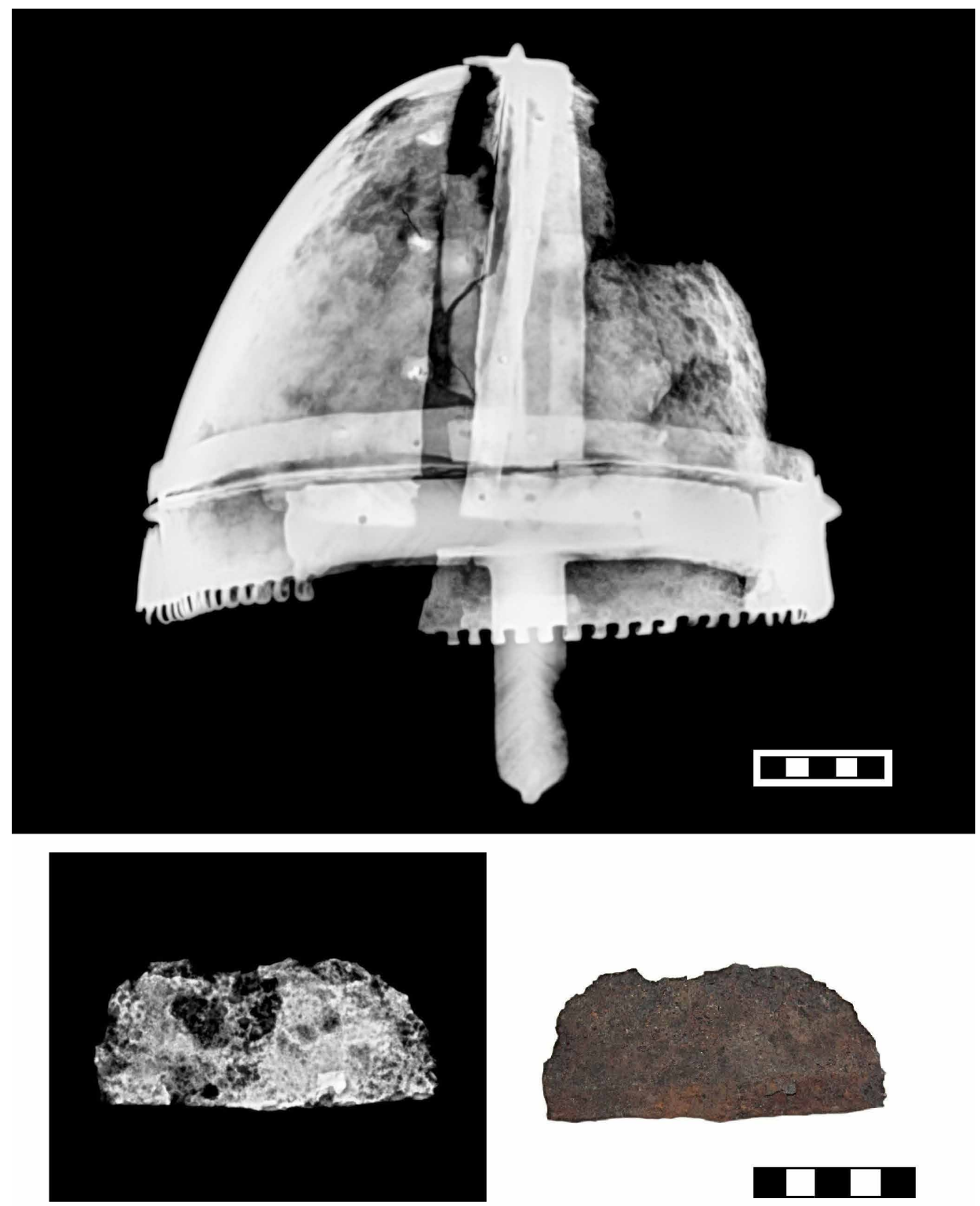

Fig. 8. Helmet from the Kozel chateau collections, rear view in X-ray. Photo M. Tučková, modified by P. Macků. Obr. 8. Přilba ze sbírek zámku Kozel, zadní pohled v rentgenovém snímku. Foto M. Tučková, úprava P. Macků.

nosepiece which should be more narrow according to the description (comp. Fig. 56 and Fig. 58 in: Laking 1920, 46; more on the issue in Bernart 2010, 49-50; Bravermanová et al. 2019, 269). In all probability, it was a helmet from Hainburg, Austria from the Avar Rampart site incorrectly cited by Laking that also came from Count Wilczek's collections. This is supported by the comparison of a photograph published by G. F. Laking with photographs and sketches in the Zeitschrift für Historische Waffenkunde Band 6, Heft 2, i.e. the original work presenting Wilczek's collection 
to the public (comp. Laking 1920, 45, Fig. 58 and Mittelalterliche helme 1912-1914, 47, Fig. 7). The two published helmets from the Olomouc region are thus probably the same one and the "lost helmet from Moravia" is in fact a helmet from Austria.

It is important to mention in this context the nearest finds from Poland, where two conical one-piece helmets with nosepieces were discovered. Both were found in lakes. The specimen from Lake Lednicki (former Poznan Voivodeship) has a hook on the nosepiece and apertures along the bottom. There is a slight edge in the centre of the skull, from the nosepiece to the top. The helmet from Lake Orchowo (former Bydhost Voivodeship) has no hook on the nosepiece but the nosepiece is slightly widened, which might point towards its original existence. The skull was welded from two parts. This specimen is now lost. Both were dated to the 11th-12th century (Sankiewicz 2018, 126-129; Nadolski 1994, 64-65, here with further European specimens from more distant locations; Nicolle-Sarnecki 2008, 20-21).

A small fragment of a helmet was found in Opava - Jaktař, the Kostelní kopec site. It was accompanied by finds dated between 10th and 12th centuries (Baarová et al. 2006, 243; Kourril 1994, 43, 46, 56, Fig. 24:10). It cannot be determined if it comes from a conical or ribbed helmet. The fragment is in the Silesian Museum in Opava, inv. no. M 105 (Moravec 2012, 53).

Finally, there are analogies for the Kozel helmet. Two come from Prague - Bubeneč (Stromovka, Royal Game Reserve), another from Bojná, Slovakia, and the most distant find comes from Gnezdovo, Russia. The helmets from Stromovka were first published by D. Hejdová who chronologically derived them from late Roman helmets and contemporary ribbed helmets. There is no further information about the circumstances of these finds; the helmets were accompanied by fragments of chainmail including a large corroded cluster and three parts of leather straps. The author dated them to the 7th - early 8th century (Hejdová 1964, 49-54). The opinions regarding the dating were discussed by M. Bernart who considered a later dating, between the 9 th and the 12 th century, and in connection with the analogy from Gnezdovo proposed a more exact dating to the 10th century (Bernart 2010, 25-27).

Helmet no. 1 (National Museum, Dept. of Early Czech History, inv. no. H2-60751) has the dimensions of $17 \times 22.7 \mathrm{~cm}$, its height is $16 \mathrm{~cm}$ (Fig. 11:1). The skull consists of two loose-fitting parts attached to a central comb with multiple rivets with hemispherical heads $1 \mathrm{~cm}$ apart. The space between the rivets is filled with tiny metal hemispheres making up two continuous rows from the forehead to the top. The border of the helmet overlaps at the top, the front section is missing. The border was reinforced with two strips. The inner lining of the helmet is indicated by holes (Hejdová 1964, 49-51).

Helmet no. 2 (held by the same institution, inv. no. H2-60752) is more vertical, $19.5 \mathrm{~cm}$ tall with dimensions $15 \times 21.5 \mathrm{~cm}$ (Fig. 11:2). Its construction is similar to the first one, the central comb $2.5 \mathrm{~cm}$ wide joining both parts of the skull features a rib. The border $5.2 \mathrm{~cm}$ wide is attached to the skull with rivets with hemispherical heads. A metal strip was attached to the bottom edge of the border with rivets, and its bottom edge has multiple perforation for the hanging of the chain mesh covering the neck. The remains of the mesh are preserved inside (a photograph was published by Bernart 2010, 68, Fig. 38). The helmet included an individual T-shaped metal nosepiece whose upper bar was perforated to be attached to the helmet with rivets (inv no. H2-60754). It is $7.9 \mathrm{~cm}$ tall, $16.5 \mathrm{~cm}$ wide and the bottom bar widens from $1.5 \mathrm{~cm}$ to $1.7 \mathrm{~cm}$ towards the bottom. The helmets were accompanied by another three fragments of a border and possibly a part of the right section of a nosepiece. However, it is not certain which helmet the fragments come from, except for the nosepiece (Hejdová 1964, 51).

Another specimen from the nearest location with a complicated history is the helmet from the Bojná I hillfort (Topol'čany district, Slovakia). The helmet was excavated by an amateur on this site together with fragments of rings of iron and base metal making up chainmail, most probably in 1997. It was then sold to a private collector (Fig. 11:3). The vertical conical skull consists of two segments joined by a central comb with a rib, held together by multiple hemispherical rivets (Pieta 2015, 27, 30, 31, Fig. 15:5, 33, Fig. 17:1-2). Further description can be only 


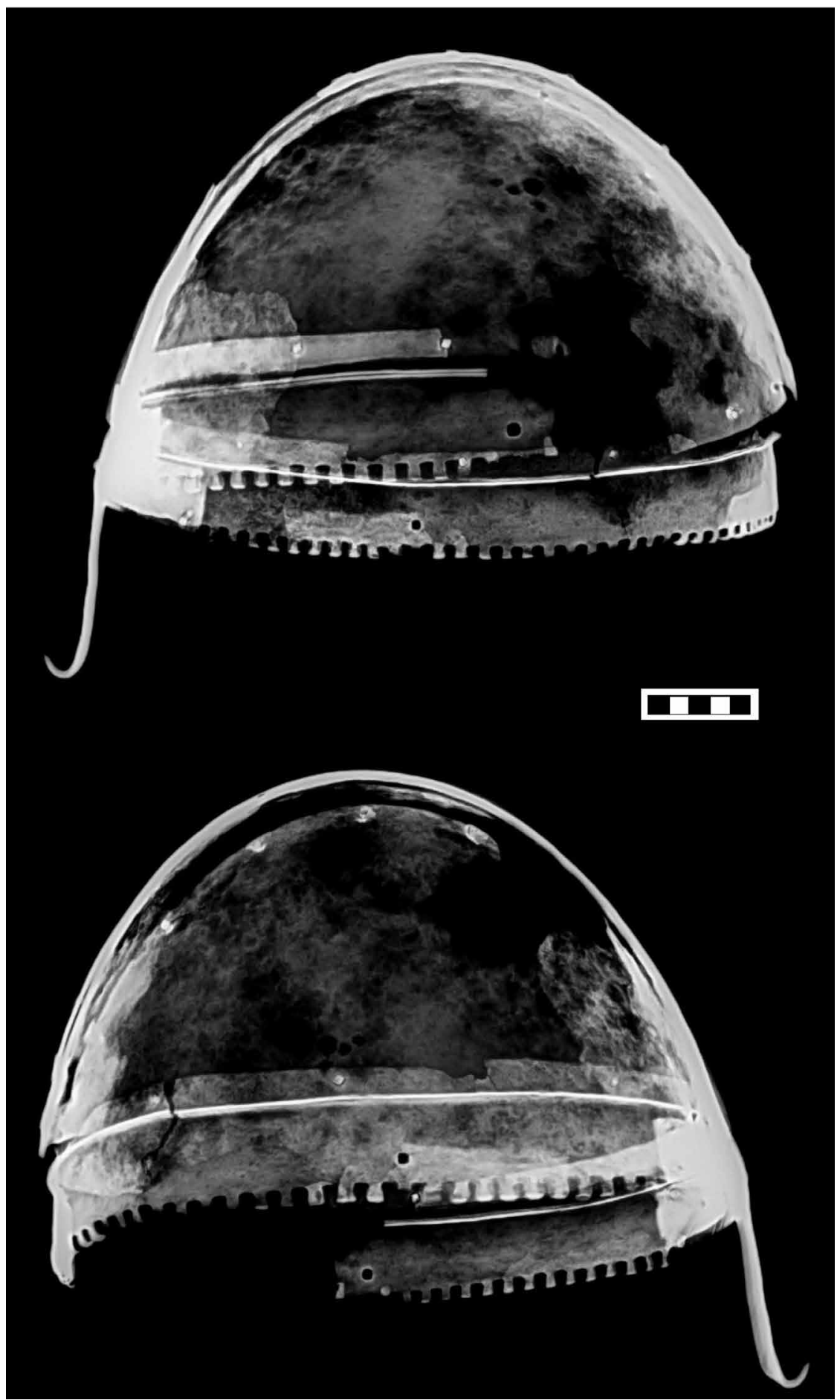

Fig. 9. Helmet from the Kozel chateau collections, side views in X-ray. Photo M. Tučková, modified by P. Macků. Obr. 9. Přilba ze sbírek zámku Kozel, boční pohledy v rentgenovém snímku. Foto M. Tučková, úprava P. Macků. 

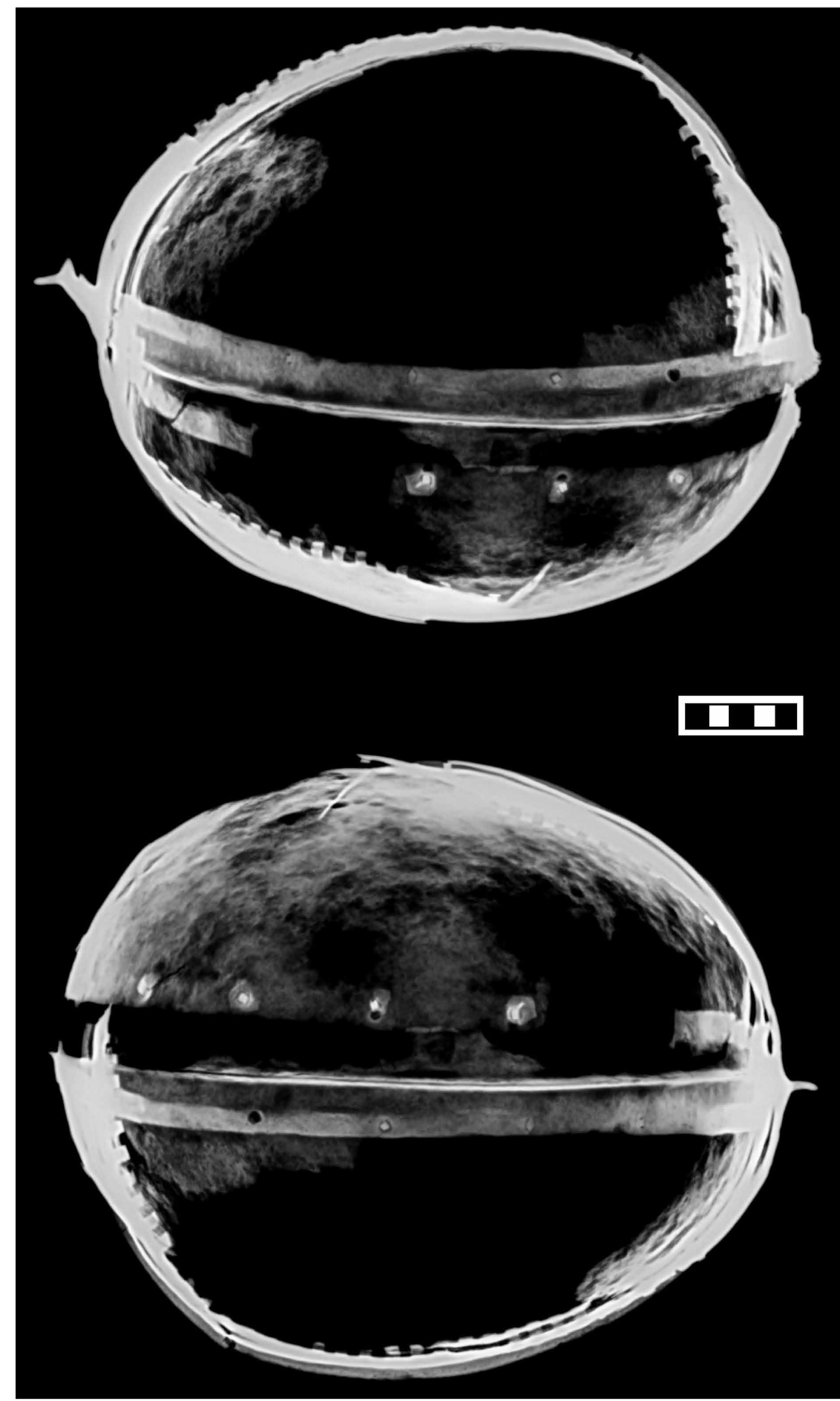

Fig. 10. Helmet from the Kozel chateau collections, top views in X-ray. Photo M. Tučková, modified by P. Macků. Obr. 10. Přilba ze sbírek zámku Kozel, horní pohledy v rentgenovém snímku. Foto M. Tučková, úprava P. Macků. 
reconstructed after a published and modified photograph. The border around the bottom of the skull was probably joined at the back and was attached to it by multiple hemispherical rivets by its upper edge. The bottom edge of the border features a chainmail holder attached in the same fashion. A T-shaped nosepiece is separate and was attached by rivets, probably five of them. The vertical bar of the nosepiece widens towards the bottom and ends in a point, there is an edge running along the centre. The circumstances surrounding the find and the further history of the helmet were investigated by T. Vlasatý who also wrote another description; unfortunately, he mainly discovered more uncertainties accompanying the helmet from its finding to its repeated disappearing (Vlasatý 2018, non-pag.).

The most distant analogy is a find from Gnezdovo I in the Smolensk region, Russia (Fig. 11:4). It was discovered by S. Sergejev in 1901 along with other militaria (mail armour and aventail, Petersen Type V sword, shield, spear head and long knife) in a double burial mound. It Is located in the State Historical Museum in Moscow, inv. no. 42536/63 (Kirpičnikov 1971, 24, 26, Tab. X:1; Kainov 2018, 219, 224-225, 228, 231). The present appearance of the helmet is the result of extensive restoration (compare the original state in Kirpičnikov 1971, Tab. X:1; Sizov 1902, 98, ryc. 68 with the present one in D'Amato 2015, 73, P1. 9; Kirpičnikov 2009, ryc. 11:1). The skull consists of two loose-fitting quarter-spheres joined by a central comb with a rib, attached by a row of rivets with hemispherical heads. A border ca $3.8 \mathrm{~cm}$ tall is attached to it by rivets and by the bottom edge is a fixture for chainmail, the fragments of which of fine mesh were found with the helmet (Kainov 2019, 189-190; 2019a, 100, Fig. 71). It is the same type of holder that occurs at with helmets from Stromovka and Bojná, but also at with pieces of other types and shapes,
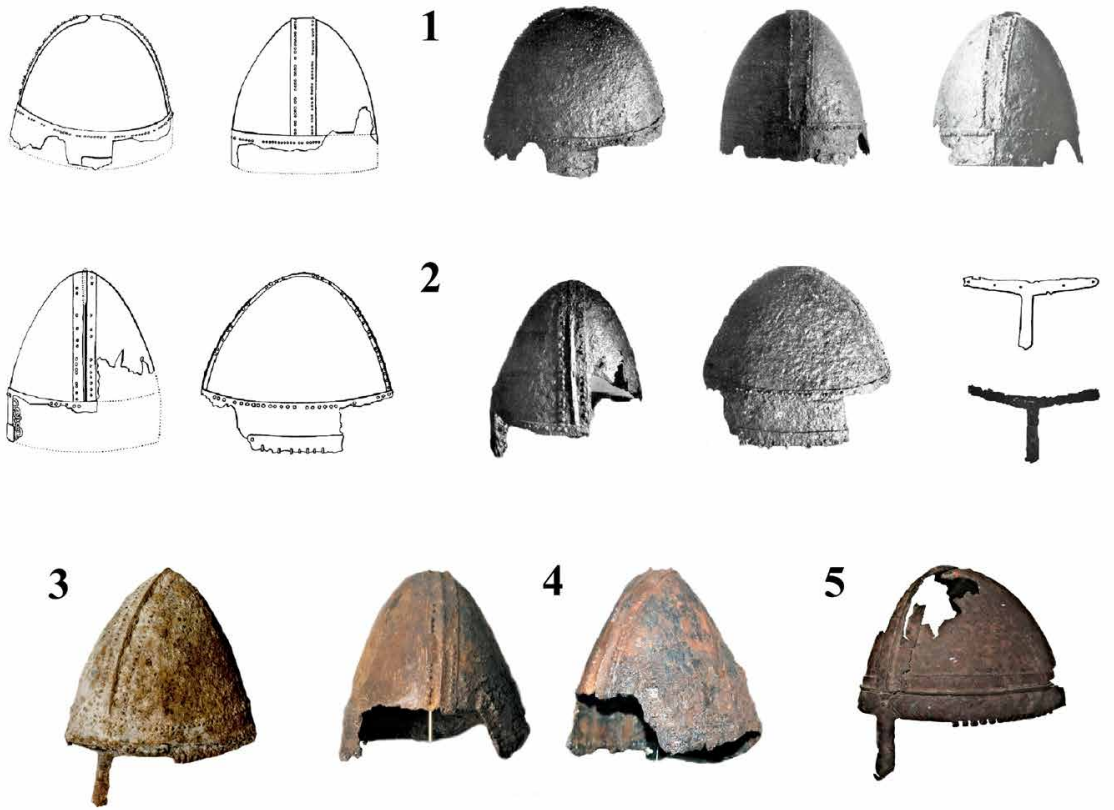

Fig. 11. Helmet from the Kozel chateau collections (5) with analogies from Stromovka, Prague (1-2), Bojná (3) and Gnezdovo, present state (4), different scales. 1-2 - after Hejdová 1964, Tab. IX: a-b, Tab. XII: a-b; 1 - on the right after Klučina et al. 1985, 70; 2 (nosepiece) - Bravermanová et al. 2019, 270, Fig. 57; 3 - Pieta 2015, 33, Fig. 17; 4 - D'Amato 2015, 73, Pl. 9, modified by P. Macků.

Obr. 11. Přilba ze sbírek zámku Kozel (5) s analogiemi z pražské Stromovky (1-2), Bojné (3) a Gnězdova, současný stav (4), rozdílná měřítka. 1-2 - dle Hejdová 1964, tab. IX: a-b, tab. XII: a-b; 1 - vpravo dle Klučina et al. 1985, 70; 2 (nánosník) Bravermanová et al. 2019, 270, obr. 57; 3 - Pieta 2015, 33, obr. 17; 4 - D’Amato 2015, 73, Pl. 9, úprava P. Macků. 
such as the find from Trnčina (Shchedrina-Kainov 2020, 230, 233, Fig. 7; a similar one is on an unspecified gilded spheroconical helmet from southern Russia, but the holder is not attached from the inner side to the skull (Kirpičnikov 2008, 67, 69, ryc. 3; 2009, 6-8, ryc. 7). Only a fragment has remained of a nosepiece, with the dimensions of $12 \times 1.8 \mathrm{~cm}$. The helmet diameter was $64 \mathrm{~cm}$, its height $21-22 \mathrm{~cm}$. The opinions of its origin vary, from western and eastern Europe to the Byzantine region. The dating ranges from the 7th century to the 10th century (Kirpičnikov 1971, 24, Tab. X:1; D'Amato 2015, 86), S. Y. Kainov dates it closely to the third quarter of the 10th century (Kainov 2018, 237; 2019, 191).

\section{Conclusion: the Stromovka-Gnezdovo-Bojná-Kozel typology line}

In terms of typology, the helmet from the Kozel chateau collections belongs in the StromovkaBojná-Gnezdovo circle, despite the fact that it has some distinctive features. Unfortunately, the contextual information for the discussed helmets, except Gnezdovo, is virtually zero. The most recent find from Bojná was made by an amateur, without any documentation, it is lost and as such not available for examination (Vlasatý 2018). Regrettably, the Kozel specimen cannot contribute to the more exact dating of this type of head protection, either, for the same reasons. The age of the helmet, even without direct evidence, can be summed up as early medieval, it is not a modern-age forgery. This opinion is supported by the listing of the helmet in "black books" compiled during the confiscation of private property by the state after 1945, where it literally says "an iron helmet from the Roman era, Ø 23" (Kozel Chateau Inventory, "black book", undated, 11). Although the only helmets of this type known at the time from the Royal Game Reserve (Stromovka) in Prague were found and passed on to the National Museum in Prague in 1938, they were only published by D. Hejdová in 1964 (1964, 49-54). Potential forgers would have had to have access to them; moreover, they would have had to provide the Kozel helmet with a large number of distinctive elements through which it differs from the Prague specimens and which make it original in details. The helmet from Gnezdovo was not known in this country at the time as it was published later, and the helmet from Bojná was discovered in the late 20th century (Kirpičnikov 1971, 24; Pieta 2015, 27).

Nonetheless, the find from Kozel expands the source base of this rare type of militaria from Central and Eastern Europe to five. When comparing them, we can see that the Kozel specimen shares some typical features, in particular, with helmet no. 2 from Stromovka, Prague and with the Gnezdovo helmet. It differs in the number of rivets used in its construction, as well as in the decorated nosepiece, the only known example of this kind preserved. The Kozel nosepiece has a hook which helmet no. 2 from Stromovka originally also had. Hooks for hanging also feature with some single-piece helmets, for example, from Olomouc - provostry, Lake Lednicki in Poland and a helmet from Augsburg (Bakker 2002). The existence of a hook is indicated by the slight widening on the helmet from Lake Orchowo, Poland. The situation is similar with the nosepiece pointed on the vertical bar covering the nose, seen on the helmet from Bojná. The common feature of the majority of these helmets is a slight widening of the nosepiece from the skull downwards. Comparing the size of non-integrated nosepieces, the largest known one is on the St. Wenceslas helmet which, however, was only added to it later. It is $19 \mathrm{~cm}$ long and $15 \mathrm{~cm}$ tall, the material is $5 \mathrm{~mm}$ thick in the bottom section (Bravermanová et al. 2019, 237, 287-290). The nosepiece on helmet no. 2 from Stromovka is $16.5 \mathrm{~cm}$ long, $7.9 \mathrm{~cm}$ tall, the thickness of the material has not been published (Hejdová 1964, 51). The incomplete nosepiece from Gnezdovo is preserved in the length of $12 \mathrm{~cm}$ and the height of $1.8 \mathrm{~cm}$, again without the thickness of the material given (Kirpičnikov 1971, 24-26). Unfortunately, there is no information regarding the nosepiece dimensions with the helmet from Bojná. The completely preserved Kozel nosepiece thus serves as an important source supplying all major metric data. Its length is $13 \mathrm{~cm}$, height $7.8 \mathrm{~cm}$ and the thickness of the material ranges from $0.2 \mathrm{~cm}$ on the left to $0.3 \mathrm{~cm}$ on the right. The rustic, yet impressive decoration is rare with this type of helmets, even in the broader context, outside the regions of the mentioned helmets. 
The thickness of metal on the skull sections of the Kozel helmet is 1-1.9 mm. The comb joining the two halves is $1.5 \mathrm{~mm}$ thick. It is less by the broken sections, decreasing to $0.2 \mathrm{~mm}$, yet we must take into account post-deposition and corrosion factors. In the Czech Republic, published data about the thickness of metal only comes from St. Wenceslas helmet, the skull of which is single-piece and was made by a different technique. Even with this helmet, however, the thickness of metal ranges from 0.6 to $2.2 \mathrm{~mm}$ (Bravermanová et al. 2019, 237, 239, 284, Figs. 11-12; Klepač 2008, non-pag.).

The missing context of the find makes a more exact dating of the Kozel helmet impossible. The dating of analogical finds from Stromovka is set in a broad chronological context between the 6th and the 12th century, most often between the 9th and the 10th century (D'Amato 2015, 86; Hejdová 1964, 53; summarized dating in Bernart 2010, 25-27). The helmets from Gnezdovo and Bojná are usually placed in the 9th -10th century (Kainov 2018, 237; Kirpičnikov 1971, 24; Pieta $2015,39,41)$. Single-piece helmets became widespread in the 10th century and were typical of the 11th and 12th centuries; consequently, it can be presumed that segmented variants consisting of several pieces, of more simple construction and production, are older (Bravermanová et al. 2019, 265). This opinion is also shared also by A. Y. Shchedrina and S. Kainov who published in detail the helmet from Trnčina, stored in held by the National Museum of Bosnia and Herzegovina in Sarajevo, inv. no. 72. According to these authors, the Trnčina helmet is similar to the Stromovka-Gnezdovo type of helmets and partially to St. Wenceslas helmet at the same time. The Trnčina helmet, being the successor to the mentioned helmets, is dated to the 11th century (Shchedrina-Kainov 2020, 236, 239, 241-242). Based on this reflection and in regard to the dating of analogical helmets, the origin of the Kozel specimen is sought in the 10th century, perhaps even in the 9 th century.

Another question, the answer to which is not provided by the Kozel example either, is the provenance of this type of helmet. Their production workshop is sought in Western Europe or the west Slavic world (Kainov 2019, 23, 190-191: see the summary of other opinions there), Moravia (Bernart 2010, 11, 27: based on the finds of mainly small ornaments of the Danube-type earrings, temple rings and bits, metal crosses, etc. in the area of Transnistria up to Gnezdovo near Smolensk, see Sedov 2001, 339; cf. Perkhavko 1985), Central and Eastern Europe (Górewicz 2020, 451-455) or Byzantium (D'Amato 2015, 86-89). Given the distribution of the known finds, we are inclined to believe that the helmets were probably made in Central Europe.

The comparative analysis of the preserved early medieval helmets from Czech territory has specified the dating of a previously published helmet from Moravia from Count Wilczek's collections, when it transpired that it was an incorrectly interpreted helmet from Hainburg, Austria. In addition, it will be necessary to examine the possible duplicity of the helmet from the vicinity of Olomouc which might be identical to the helmet from Olomouc - provostry.

\section{Sources}

KOZEL CHATEAU INVENTORY, “black book”, Plzeň, National Cultural Committee, undated (after 1945), archive of the National Heritage Institute, Plzeň branch.

SOA Prague, Štáhlavy Estate file, inv. no. 452, file card 64.

SOA Prague, Mnichovo Hradiště file, RAV, inv. no. 3372, sign. II-5 (Memoirs of Christian Vincent of Waldstein-Vartenberk).

SOA Prague, Mnichovo Hradiště file, RAV, inv. no. 3375, sign. II-6/I/1-8, file card 34, folio 23 (Letter from E. Vocel).

Exhibition

PILNÁ, V.-KASL, F.-JÍCHOVÁ, V.: The Waldsteins and the Origins of Archaeology in the Stáhlavy Demesne. Exhibition of the National Heritage Institute, Plzeň, 21. 12. 2020 - 30. 4. 2021. 


\section{Bibliography}

BAAROVÁ, Z.-FRAIT, R.-SOVKOVÁ, V.-ŠLANCAROVÁ, V., 2006: Sága moravských Přemyslovců. Život na Moravě od XI. do počátku XIV. století. Olomouc - Brno.

BAKKER, L., 2002: Nasalhelm. In: Kaiser Heinrich II. 1002-1024 (Kirmeier, J.-Schneidmüller, B.-Weinfurter, S.-Broskhoff, E., edd.), 244. Augsburg.

BATĚK, J., 1967: Z dějin Štáhlav. Blovice.

BEAUFORT, CH.-PFAFFENBICHLER, M., 2005: Meisterwerke der Hofjagd- und Rüstkammer. Kunstführer durch das Kunsthistorische Museum. Band 3. Wien.

BERNART, M., 2010: Raně středověké přilby, zbroje a štíty z českých zemí. Diploma work, Institute of Prehistory and Early History, Faculty of Arts, Charles University, Prague, superisor Prof. PhDr. Jiří Sláma, CSc.

BLAIR, C., 1959: European Armour. Circa 1066 to circa 1700. New York.

BRAVERMANOVÁ, M., 2011: The so-called armour of St. Wenceslaus - a historical introduction, Acta Militaria Mediaevalia XI, 213-220.

BRAVERMANOVÁ, M.-LEDVINA, P.-HAVLÍNOVÁ, A.-PERLÍK, D., 2019: Nová zjištění o přilbě a zbroji zv. Svatováclavské, ASČ 23, 235-310.

BROŽEK, P., 2021: Platnéřství. Praha.

D'AMATO, R., 2015: Old and new evidence on the East-Roman helmets from the 9th to 12th centuries, Acta Militaria Mediaevalia XI, 27-157.

FRANC, F. X., 1988: Štáhlauer Ausgrabungen 1890. Díl 1. Přehled nalezišt’ v oblasti Mže, Radbuzy, Úhlavy a Klabavy 1906 (ed. Věra Šaldová). Praha.

GOLL, J., 1898: František Palacký, ČČH 1898, 16-279.

GÓREWICZ, I. D., 2020: O broni Słowian. Na wojnie I v kulturze. Szczecin - Poznań.

HANUŠ, J., 1923: Národní museum a naše obrození k stoletému jubileu založení musea 2. Založení vlasteneckého musea v Čechách a jeho vývoj do konce doby Šternberkovy (1818-1841). Praha.

HEJDOVÁ, D., 1964: Přilba zvaná „svatováclavská“, SbNM A XVIII, 1-106.

JÍLKOVÁ, E.-RYBOVÁ, A.-ŠALDOVÁ, V., 1959: Mohylové pohřebiště na Hájku u Štáhlav, okres Plzeň, PA L, 54-119.

ZE JOINVILLU, J., 2014: Život Ludvíka svatého, krále francouzského. Vyznání víry / List Ludvíkovi X. Memoria medii aevi. Vol. 21 (Moravová, M., ed.). Praha.

KAINOV 2018 / Каинов, С. Ю., 2018: Погребения с предметами вооружения Гнёздовского некрополя. Гнёздовский археологический комплекс: Материалы и исследования. Вып. 1 (Отв. ред. С. Ю. Каинов), 212-241. Москва.

- 2019: Сложение комплекса вооружения Древней Руси X - начала XI в. (по материалам Гнёздовского некрополя и поселения). Диссертация на соискание ученой степени кандидата исторических наук, Том І. Москва.

- 2019а: Сложение комплекса вооружения Древней Руси X - начала ХІ в. (по материалам Гнёздовского некрополя и поселения). Диссертация на соискание учѐной степени кандидата исторических наук, Том II. Москва.

KAREL IV., 2006: Karel IV. Císař z Boží milosti. Kultura a umění za vlády Lucemburků 1310-1437 (Fajt, J., ed.). Praha.

KIRPIČNIKOV, А. N., 1971 / Кирпичников, А. Н., 1971: Древнерусское оружие: Вып. 3. Доспех, комплекс боевых средств IX-XIII вв. АН СССР. Москва.

- 2008: Восстановленная антикварная воинская редкость. Новые наблюдения о раннесредневековых золоченых шлемах. In: Дьнєслово: Збірка праць на пошану дійсного члена Національної академії наук України Петра Петровича Толочка з нагоди його 70-річчя, 67-75. Київ.

- 2009: Раннесреднебекобые золоченые шлемы новые находки и наблюдения. Санкт-Петерург.

KLEPAČ, J., 2008: Př́ilba svatého Václava po řemeslné stránce. Rukopis ze sbírek oddělení uměleckých sbírek Správy Pražského hradu, inv. no. K 167, non-pag.

KLUČINA, P.-MARSINA, R.-ROMAŇÁK, A., 1985: Vojenské dějiny Československa. 1. díl (do roku 1526). Praha. 
KNÁPEK, A.-MACKU゚, P., 2016: Unikátní součást zbroje z hradu Ronovce (okres Havlí̌kův Brod) Ein einzigartiger Bestandteil einer Rüstung von Burg Ronovec (Bezirk Havlíčkủv Brod), AH 41, 167-180. https://doi.org/10.5817/AH2016-2-7

KOLÁŘ, M., 1875: Památky na Plzeňsku, Památky archaeologické a místopisné X, 417-424.

KONDELÍK, M.: Archeologie v západních Čechách do roku 1950. Plzeň.

KOUŘIL, P., 1994: Slovanské osídlení českého Slezska. Brno.

LAKING, G. F., 1920: A record of armour and arms through seven centuries. Vol. I. London.

VON LENZ, E., 1924: In Russland gefundene frühmittelalterliche Helme, I. Beiheft der Zeitschrift für historische Waffen- und Kostümkunde.

MACKU゚, P.-PILNÁ, V., 2020: Vrcholně středověký nánosník z mobiliárního fondu státního zámku Kozel jako př́íklad prvních archeologických výzkumů a možnosti jeho interpretace - Ein hochmittelalterliches Nasal aus dem Mobiliarbestand des staatlichen Schlosses Kozel als Beispiel für die ersten archäologischen Grabungen und Möglichkeiten seiner Interpretation, AH 45, 391-402. https://doi.org/10.5817/AH2020-1-18

MACHÁČEK, F., 1909: Městské historické museum v Plzni, jeho vývoj a jeho úkoly. Plzeň.

MACHÁČEK, F.-STRNAD, J., edd.: Sborník městského historického musea v Plzni. Svazek IX. Plzeň.

MĚŘíNSKÝ, Z., 2009: Morava součástí přemyslovského státu. In: Přemyslovci. Budování českého státu (Somer, P.-Třeštík, D.-Žemlička, J., edd.), 219-227. Praha.

MITTELALTERLICHE HELME: Mittelalterliche Helme aus dem Besitze Sr. Exz. Des Grafen Hans Wilczek. Sammlung Schlofs Kreuzenstein, Zeitschrift für Historische Waffenkunde, Band 6, Heft 2, 41-47.

MORAVEC, Z., 2012: Část přilby z Opavy - Jaktaře. In: Cesta ke Zlaté bule sicilské. Usilování o královskou korunu (Barcuchová, K.-Moravec, Z., edd.), 53. Ostrava.

NADOLSKI, A., 1994: Polska technika wojskova do 1500 roku. Z dziejów nauki i techniki 1. Warszawa.

NICOLLE, D.-SARNECKI, W., 2008: Medieval Polish Armies 966-1500. Oxford.

PERKHAVKO 1985 / Перхавко, V. В., 1985: Западнославянские элементы в раннесредневековой культуре междуречьа Днепра и Немана, Краткие Сообщения 187, 28-35.

PIETA, K., 2015: Včasnostredoveké mocenské centrum Bojná - výskumy v rokoch 2007-2013. In: Bojná 2. Nové výsledky výskumov včasnostredovekých hradísk (Pieta, K.-Robak, Z., edd.), 9-49. Nitra.

PÍČ, J. L., 1890: O zbroji starých Slovanů, Památky archeologické a místopisné XV, 1-14.

Plzeňské listy, 6. 9. 1906.

RANDOVÁ, J., 2010: František Xaver Franc: Život a dílo, AZČ 1, 5-7.

SANKIEWICZ, P., 2018: Hełm stożkowy z jeziora Lednica. In: Broń drzewcowa I uzbrojenie ochronne z Ostrowa Lednickiego, Giecza I Grzybowa. Pole Weapons and Armour from Ostów Ledniciki, Giecz and Grzybowo, 123-131. Lednica.

SEDOV, V. V., 2001: O migraci Slovanů ze středního Podunají do východní Evropy. In: Velká Morava mezi východem a západem - Großmähren zwischen West und Ost (Galuška, L.-Kouřil, P.-Měřínský, Z., edd.), 339-247. Brno.

SIZOV 1902 / Сизов, В. И., 1902: Курганы Смоленской губернии І. Гнездовский могильник близ Смоленска. Материалы по археологии России 28. Санкт-Петербург.

SOMMER, J. G., 1838: Das Königreich Böhmen. Statistisch-topographisch dargestellt. Band 6 - Pilsner Kreis.

SEDLÁČEK, A., 1905: Hrady, zámky a tvrze. Vol. 13. Praha.

SHCHEDRINA, A. Y.-KAINOV, S., 2020: Helmet from The National Museum of Bosnia and Herzegovina, Acta Militaria Mediaevalia XVI, 225-245.

SKLENÁŘ, K., 2000: Archeologie a pohanský věk. Př́iběhy z dětských let české archeologické vědy. Praha. - 2017: Archeologie v Čechách v období analytického positivismu. Praha.

STRONG, D. W., 2018: Surviving Examples of Early Plate Armour (1300-1430). Volume I: Bascinets. Wheaton.

THOMAS, B.-GAMBER, O., 1976: Katalog der Leibrüstkammer. I. Teil. Der Zeitraum von 500 bis 1530. Wien.

VALDSTEIN, E. K., 1887: Die Wigalois-Bilder im Sommerhausse der Burg Rungelsstein. In: Mittheilungen der kaiserl. königl. Central-Commission zur Erforschung und Erhaltung der Baudenkmale, 159-165. Wien. 
- 1894: Nachlese von Rungelsstein. In: Mittheilungen der kaiserl. königl. Central-Commission zur Erforschung und Erhaltung der Baudenkmale, 1-7. Wien.

- 1893: Eine Gräberstätte bei Dauba, Mittheilungen des Nordböhmischen Excursions-Clubs, Nordböhmischer Excursions-Club 3, 1-22.

VELKOVÁ, A., 2009: Krutá vrchnost, ubozí poddaní? Praha.

VLASATÝ, T., 2018: The Helmet from Bojná (?), Slovakia. One of the biggest mysteries of Slovakian Early Medieval archeology. Unpublished manuscript in P. Mackůs archive, non-pag.

- in press: Katalog evropských přileb 9.-12. století. Manuscript in P. Macků’s archive.

ZAP, K. V., 1854: Jednání a činnost archeologického odboru Českého Museum. In: Památky archaeologické a místopisné, organ Archaeologického sboru Musea království Českého a Historického spolku v Praze, Praha, no. 1, 42-46.

\section{Resumé}

\section{Raně středověká přilba typu Stromovka-Gnězdovo-Bojná ze sbírek státního zámku Kozel}

Ve sbírce státního zámku Kozel se nachází dosud nepublikovaná raně středověká přilba, sestávající ze dvou fragmentů, pod inventárním číslem KZ 3480 (původní č. 249/bč/134). Celková váha činí 703 gramů. Přilba byla snýtována z pěti částí (obr. 1). Skládá se ze dvou čtvrtkulovitých zvonů na středu spojených páskovým hřebenem se středovou kanelou, které jsou při spodní hraně navíc snýtovány lemem s očky pro uchycení barmice (obr. 3-4, 9). V místě čela je napevno uchycen nánosník tvaru T s reliéfní rustikální výzdobou (obr. 2, 5-7). Vnější obvod přilby činil okolo $65 \mathrm{~cm}$, což je údaj získaný kvůli fragmentárnosti odhadem, nicméně velmi pravděpodobný. Rozměr od týlového okraje k čelu (bez nánosníku) činí $41,5 \mathrm{~cm}$. Výška přilby včetně nánosníku je $21,5 \mathrm{~cm}$, šířka taktéž $21,5 \mathrm{~cm}$.

Přilba ze sbírek zámku Kozel patří typologicky k okruhu Stromovka-Bojná-Gnězdovo, i když nese svébytné znaky v provedení (obr. 6). Bohužel jsou nálezové informace k daným přilbám, vyjma Gnězdova, takřka nulové. Nejnovější nález z Bojné byl učiněn amatérsky bez dokumentace a je navíc opět pro badatelské účely ztracen (Vlasatý 2018). Ani kozelský exemplář tak nemůže přispět k jistějšímu datování či určení provenience tohoto typu ochrany hlavy. Stáří přilby, i bez př́imých důkazů, můžeme označit jako raně středověké, nikoli jako novodobý falzifikát. Vede nás k tomu uvedení přilby v tzv. černých knihách psaných při konfiskaci majetků státem po roce 1945, kde je výslovně uvedeno „,helma železná z doby románské, Ø 23“(Inventář zámku Kozel, nedat., 11). Ačkoli byly v tu dobu jediné známé prrilby tohoto typu z Královské obory (Stromovky) v Praze nalezeny a předány Národnímu muzeu v Praze už v roce 1938, publikovány byly až v práci D. Hejdové v roce 1964 (Hejdová 1964, 49-54). Případný falzifikátor by k nim musel mít přístup a vtisknul by do kozelské přilby poměrně dost svérázných prvků, které ji vzhledem k pražským nálezům činí v detailech originální. Přilba z Gnězdova v tu dobu u nás taktéž nebyla známa, byla publikována až později, a přilba z Bojné byla objevena až v závěru 20. století (Kirpičnikov 1971, 24-26; Pieta 2015, 27).

Chybějící nálezové okolnosti znemožňují jistější dataci kozelské přilby. Datace analogických kusů z pražské Stromovky je hledána v širokém časovém úseku od 6. do 12., nejčastěji v 9.-10. století (D’Amato 2015, 86; Hejdová 1964, 53; souhrnně k datování Bernart 2010, 25-27). Přilby z Gnězdova a Bojné jsou ponejvíce kladeny do 9.-10. století (Kipričnikov 1971, 24; Pieta 2015, 39, 41). Nastupují-li jednokusové přilby do běžnějšího užívání v 10. století a typické jsou pro 11. a 12. století, pak lze soudit, že konstrukčně a výrobně jednodušší varianty složené z více dílů budou starší (Bravermanová et al. 2019, 265). Na základě této úvahy s velkou opatrností a s přihlédnutím $\mathrm{k}$ názorům na dataci analogických přileb můžeme uvažovat o tom, že původ kozelského exempláře leží v 10., snad i v 9. století.

Materiálové analýzy nemohly být dosud provedeny kvůli koronavirové pandemii. Budou předmětem dalšího bádání před konzervací přilby a budou samostatně publikovány. 
Při srovnávací analýze dochovaných raně středověkých přileb z našeho území zároveň došlo k upřesnění dříve publikované přilby ze sbírek hraběte Wilczka nalezené na Moravě, kdy se ukázalo, že jde pouze o mylně interpretovanou přilbu z Hainburgu v Rakousku. Také by bylo ještě potřeba ověřit možnou duplicitu přilby z okolí Olomouce, která by mohla být „pouze“ přilbou z Olomouce - proboštství (srov. Laking 1920, 45, 46, Fig. 56-58 s Mittelalterliche helme 1912-1914, 47, obr. 7; k problematice Bernart 2010, 49-50; Bravermanová et al. 2019, 269).

Mgr. Pavel Macků, Archeologický ústav Filozofické fakulty Jihočeské univerzity, Branišovská 31a, 37005 České Budějovice, Česká republika, mackup01@fff.jcu.cz

Mgr. Veronika Pilná, Ph.D., Národní památkový ústav, územní odborné pracoviště v Plzni, Prešovská 7/1171, 30627 Plzeň, Česká republika, pilna.veronika@npu.cz 